\title{
THE CONSTITUTIONAL MODEL OF ADMINISTRATIVE DISCRETION IN UKRAINE: DESIGN OR SPONTANEOUS ORDER
}

Purpose. The purpose of the study is to analyze the constitutional model of administrative discretion in Ukraine through the prism of F.A. Hayek theory about design and spontaneous order. The additional purpose of the study is to propose changes to the model of the administrative discretion in Ukraine.

Methods. The qualitative research method was fundamental in the proposed study. The traditional (non-empirical) legal research approach was a major tool in the study model of administrative discretion in Ukraine.

Results. The problem of inefficiency of the model of administrative discretion in Ukraine is studied by the author in the article. The provisions of part 2 of Article 19 of the Ukrainian Constitution are criticized. Limitation of administrative discretion of public officials by the law are considered ineffective. The reasons for the ineffectiveness of the model of administrative discretion are the disregard for spontaneity in the process of drafting legislation, according to the author's assumptions. Thus, the author uses the concept of spontaneous order, which was created by the Austrian economist F.A. Hayek. In accordance with this concept, the disadvantage of the planning system is the inability to predict all situations that may occur in real life. This conclusion can also be applied to the process of creating legislation. Accordingly, the author concludes that the laws cannot provide a perfect code of conduct for public officials.

Conclusions. Thus, the author concludes that limiting administrative discretion to the law is not the best solution. The article proposes to restrict administrative discretion not by law, but by legal principles. According to the author, it takes into account the element of spontaneity in public administration. However, the author also emphasizes that the role of judicial review of administrative acts is significantly increasing in such a model.

Key words: administrative discretion, spontaneous order, constitutional design, public administration. 


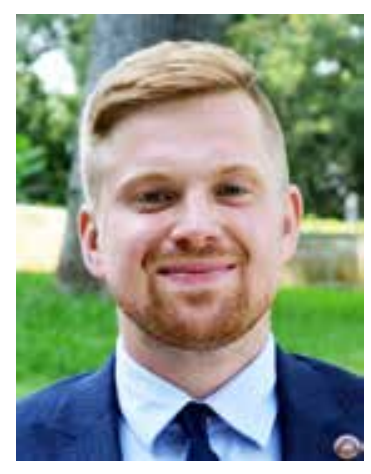

Oleksandr Sydielnikov,

Master of Laws (LL.M.) Candidate Program in Rule of Law for Development (PROLAW) Rule of Law for Development Institute Loyola University Chicago School of Law - John Felice Rome Center, Ph.D. o.sydielnikov@gmail.com
If we delegate too much decision-making authority to experts, administration and democracy conflict. We lose control. Yet if we delegate too little authority, we also find democracy weakened.

Justice Breyer "Active Liberty: Determining our Democratic Constitution" (Clayton, 2015)

\section{Introduction}

The problem of inefficiency of the model of administrative discretion in Ukraine is studied by the author in the article. Limitation of administrative discretion of public officials by the law are considered ineffective. The reasons for the ineffectiveness of the model of administrative discretion are the disregard for spontaneity in the process of drafting legislation, according to the author's assumptions. Thus, the author uses the concept of spontaneous order, which was created by the Austrian economist F.A. Hayek.

The purpose of the study is to analyze the constitutional model of administrative discretion in Ukraine through the prism of F.A. Hayek theory about design and spontaneous order. The additional purpose of the study is to propose changes to the model of the administrative discretion in Ukraine.

2. Criticism of the modern model of administrative discretion in Ukraine

Administrative discretion is one of the most important and complicated categories in the administrative law. The important role of administrative discretion is conditioned by the close relationship between the discretion of the public administration and the rule of law. The origin of administrative discretion is contained in the concept of the rule of law. A well-known British scientist Albert Venn Dicey at the end of the nineteenth century provided quite popular definition of one of the components of the rule of law: "No man is punishable or can be lawfully made to suffer in body or goods except for a distinct breach of law established in the ordinary legal manner before the ordinary Courts of the land" (Dicey, 1902: 183-184). This expression means a more general idea that forms the rule of law. Government power should be limited by law in order to prevent state arbitrariness. Therefore, this idea is extremely important. As a consequence, many constitutions, which were adopted around the world, restricted government power by the law. Such a model really creates safeguards against government arbitrariness in many countries.

The Ukrainian constitution also contains a similar idea. The second paragraph of Article 19 of the Constitution states 
the following: "Public authorities and bodies of local self-government and their officials shall be obliged to act only on the grounds, within the powers, and in the way determined by the Constitution and the laws of Ukraine" (Verkhovna Rada of Ukraine, 1998). Such norm creates a strict limitation for any discretionary powers of the government. It is extremely difficult to abuse the powers under such conditions.

Accordingly, Ukrainian legislation contains many laws, regulations, and instructions that regulate every official's actions. However, it is clear that nobody can predict and plan all circumstances, situations and write laws which will ideally regulate all aspects of the activities of public officials. In this context, Scott Clayton noted the following: " $<\ldots$..> scholars have pointed out on practical grounds that agency's authorizing legislation is often vague and it is impossible to legislate for all possible administrative scenarios, thus requiring a significant amount of administrative discretion to make legislation functional" (Clayton, 2015). But even the rule of law allows a certain freedom of government bodies in public administration. Such freedom is an administrative discretion.

A discretionary action is informal and, therefore, unprotected by the safeguards inherent in a formal procedure. A public official, for example, has administrative discretion when he or she has the freedom to make a choice among potential courses of action. However, such freedom, in accordance with the Ukrainian constitution, is extremely limited.

As a result of such a limited model of administrative discretion, public officials are unable to regulate their areas of responsibility. They either move away from solving certain problems or solve them inefficiently. Also, they often complain that the legislation is imperfect and does not take into account all the situations which arise in real life. In fact, such a model destroys any initiative, variability, and pluralism in public administration. Although bureaucracy is not dangerous, but extremely inefficient and not able to respond properly to the demands of society. It is clear that the reason for such negative consequences lies in the model of administrative discretion existing in Ukraine.

Thus, we can assume that there is a significant difference between the planning of administrative laws and real life, which may be unpredictable. Nevertheless, the threat of arbitrariness cannot be a justification for the lack of efficiency of public administration.

\section{Design or spontaneous order}

The reasons for the weakness of the administrative discretion model in Ukraine emerge from the imperfection of the legislative planning system. The design of laws and instructions that govern the activities of public officials has an initial disadvantage. As noted earlier, such a system is theoretically unable to take into account all possible situations, which may arise in public administration. Solving this problem is possible through combining design and spontaneous order.

The detailed consideration of this discussion requires the use of the theory of economist F.A. Hayek, who tried to explain the existing systems of orders in the world. In his fundamental study "Law, Legislation and Liberty", he suggests that any human behavior within society is part of two systems of order. According to Hayek, usually, order is described like something that:" $\langle\ldots>$ must rest on a relation of command and obedience, or a hierarchical structure of the whole of society in which the will of superiors, and ultimately of some single supreme authority, determines what each individual must do" (Hayek, 1982: 36). Such understanding of the order means that the managed and controlled system has a hierarchy, structure, and a clear subordination. In such systems, 
the subordinate must clearly comply with the orders of the superior. The manager or authority clearly plans the rules and gives appropriate instructions.

However, Hayek emphasizes that there are other systems different from the planning systems of order. According to Hayek, the essence of the concept of a planning system of order is authoritarian. It is created and coordinated from the outside. A system of spontaneous order, where the development of an entire system depends on its constituent elements, is opposite to planning (Hayek, 1982: 36). Thus, the difference between the two systems is that the planning system of order is somewhat artificial and can be characterized as an organization. While another system is inherent in self-regulation and it can be characterized as spontaneous order (Hayek, 1982: 37).

Hayek's ideas about systems of order can be used to describe the model of administrative discretion in Ukraine. If we try to extrapolate this scheme to an administrative discretion model, then we will be able to see that in this model there are both elements of planning and spontaneous order. Planning elements are manifested in the fact that administrative discretion is a part of public administration. Usually, public administration in Ukraine is a total organization and planning system. Public administration is fully governed from the outside since public officials should act only in accordance with the rules established by law. Officials themselves, as elements of such a system, have no influence on the system as a whole.

The idea of Ukrainian public administration is based on the following provisions. The activities of public officials are fully regulated by laws, instructions which provide a rule for each of their actions. Public officials do not make their own decisions but only act in accordance with laws. The system of public administration has a clear hierarchical structure. In this structure, every official person must follow the orders of his supervisor. Therefore, we can conclude that this is a classic planning system of order, in accordance with the theory of Hayek. And this is not surprising, because such a system is typical for a government mechanism.

Administrative discretion, as an integral part of public administration, is characterized by spontaneity. Rather, administrative discretion is kind of spontaneous order in public administration. Administrative discretion is the freedom of an official to choose an option of behavior. A public official can choose an option of behavior if the law gives several equivalents of behavior. This is very small freedom of behavior, which is limited by laws. Nevertheless, it corresponds to the model of spontaneous order. The existence of the concept of administrative discretion is, in fact, a recognition that the planning system of order is not able to solve all the problems that exist in public administration.

That is why public administration must take into account the element of spontaneity. It is necessary to give some freedom to the authorities. This freedom is important in those areas where planning is very difficult or ineffective. Today, there is an increasing tendency to outsource some areas of public administration to the private sector. As Rebecca L. Keeler notes: " $<\ldots$.. an increasing share of public services is being outsourced to the private sector, much of administrative law is not applicable to governments' contracted agents" (Keeler, 2013: 183). In the modern world, there is an increasing number of new spheres of social life that are difficult to regulate in advance by pre-established rules. In such new areas, officials should have a certain level of freedom in order for public administration to be effective. Despite the fact that administrative discretion is becoming popular throughout the world, its use in Ukraine remains limited. The administrative 
discretion of Ukrainian officials is very restricted and extends not to all areas of public administration.

Therefore, in order to make administrative decisions more effective, it is necessary to find the most optimal model for it. In this context, one should answer the question which Scott Clayton was interested in:

An enduring question regarding administrative discretion is how to make the bureaucracy efficient and effective while also ensuring accountability through democratic values of representation and fairness. In other words, how much administrative discretion is appropriate and how best to regulate the regulators? (Clayton, 2015)

The next part of the study is an attempt to answer this question and offer the most optimal constitutional model of administrative discretion.

4. The dilemma between design and spontaneous order: which model is better for administrative discretion

Since the time Hayek researched this problematic, study of the problems of planning and spontaneous order attracted the attention of many scholars. Discussions focused on which of these two systems is better for regulating certain spheres of social life. A similar debate about the law also took place. Such scholars as Caryn Devins, Roger Koppl, Stuart Kauffman, and Teppo Felin were against planning system of order. In their study, they considered the US Constitution as a design object. They tried to understand whether the planning of the founders of the Constitution was really effective or ineffective. Can constitutional rules that were adopted 225 years ago be useful at our time? (Devins et al., 2015: 609). In fact, their research question was whether the constitutional design was a good decision and how to interpret the US constitution in the modern world?

They believe that planning or design are not effective in relation to the Constitution. The authors wrote: "We are against design, not because we oppose planning and foresight. Not because we oppose action to make a better future. We are against design because it is impossible" (Devins et al., 2015: 679). The scientists explained that the constitutional creator does not have all the knowledge that is necessary to anticipate all the situations in the future. They also noted that it is impossible to predict how such a law will be applied in the future. The behavior of public servants often is unpredictable, and therefore, even a good constitution design could be used illegally (Devins et al., 2015).

Their attitude about this issue is well illustrated in the following passage:

Our analysis suggests that two leading theories of constitutional interpretation, originalism and living constitutionalism, are both unsatisfactory. Originalists do not adequately recognize that the present differs from the past. Novel situations unimaginable to the framers make it possible to have multiple, inconsistent, but equally originalist interpretations of the Constitution. Living constitutionalists do not adequately recognize that the future will differ from the present. Present interpretations enable entirely new and unforeseen laws, which may produce outcomes opposite to those intended by the crafters of present interpretations. For this reason, both theories have morphed over time and become more similar, showing that theory itself defies design (Devins et al., 2015: 609).

Despite the fact that scientists criticize the constitutional design, they do not solve all the problems existing in this area (Devins et al., 2015: 680).

Steven Calabresi demonstrates a more balanced view of this issue. He believes that the position of the previous authors is too critical and that the US constitutional design 
in the historical retrospective has proven to be successful (Calabresi, 2016: 239). The following passage shows his position regarding the success of the institutional design.

The success of the Planned System of Order, which is the U.S. Constitution, is readily discernable. Thanks to our Constitution, the United States is the third largest country in the world by territory, the fourth most populous country in the world, and is the world's only military superpower. The U.S. economy is the largest economy in the world, and the U.S. has by far the highest GDP per capita of any of the so-called G-20 nations. The superior constitutional design of the U.S. Constitution is in many ways responsible for all of these successes (Calabresi, 2016: 239).

Thus, Calabresi wrote that the Constitutional design is effective and it will be wrong to completely deny it. However, he makes a more important conclusion. He notes that design and spontaneous order does not exist in isolation, but always interact and complement each other (Calabresi, 2016: 240). According to this idea, two systems of order balance each other and fill the gaps of each other. And this is very different from the position of the authors of "Against design".

Which conclusions from this comparison can be made for the Ukrainian model of administrative discretion? It should be noted that the view of Calabresi is absolutely balanced and rational. This means that the institutional model of administrative discretion presented in the study will be determined by combining planning and spontaneous order. That will solve many of the problems existing in this area, including the following: 1) the lack of variability of officials in public administration; 2 ) their inability to solve new problems that are not yet regulated by law; 3 ) the inability to negotiate and conduct a dialogue with citizens; 4) failure to provide public interest in public administration; 5) inability to implement projects in cooperation with private business. A combination of design and spontaneous order will help solve all these problems.

Therefore, in order to improve the model of administrative discretion in Ukraine, several circumstances should be taken into account. It is necessary to provide more freedom and variability of officials in decision-making process. At the same time, an effective control mechanism must be provided. Excessive freedom of public officials may lead to arbitrariness and human rights violations. Hence, effective control is extremely demanded. However, it is important to start with the design aimed at expanding the freedom of public administration.

At the beginning of the work, a constitutional model of administrative discretion was described. It is not difficult to understand that it severely restricts public officials in Ukraine. Currently, Article 19 of the Constitution of Ukraine defines law as a factor that limits administrative discretion. This is a pure design model. The laws that are created and adopted by the parliament are a kind of plan that defines the organizational activities of the bureaucracy. Accordingly, the expansion of freedom in this constitutional model of the institute of administrative discretion is a manifestation of spontaneous order. This will increase the importance of the official's personality and allow them to influence the processes in society.

In fact, the problem is reduced to the following. If the law, as a limitation of administrative discretion, is a manifestation of design, then what will be more focused on spontaneous order? Such a limiter may be legal principles. Principles such as legitimacy, rule of law, proportionality, transparency, accountability, and many other similar principles are more focused on the regulation of spontaneous situations. They are not rigidly planned 
by the legislator but allow the public servant to be more flexible and more focused on each particular situation. At the same time, the focus on legal principles during public administration cannot be arbitrary, since the legal principles do not justify the violation of human rights. Therefore, the proposed model is completely correlated with the rule of law and does not contradict this concept.

Undeniably, such a constitutional model will develop the role of judicial review of administrative acts. The administrative courts will interpret each case in compliance with legal principles. The increasing role of judicial review indicates that this model is more focused on spontaneous order than on planning. If the administrative discretion in the Constitution is limited by legal principles, this may lead to an incorrect interpretation of such principles in practice. In these cases, the role of administrative courts, which in accordance with Ukrainian legislation, have the right to review administrative acts of executive power (Verkhovna Rada of Ukraine, 2005), will rise. The role of administrative courts will be significant in this model. By expanding the administrative discretion of public officials, we open up opportunities for abuse. The administrative court is only one restraining institution in this case. Therefore, the judicial review of each particular conflict situation can reconcile the concept of planning with unforeseen situations that may occur in real life.

However, it is necessary to consider additional mechanisms to prevent abuse by public officials. Such fuses would be to introduce additional requirements for the civil service ethics and transparency (Keeler, 2013; 183).

5. Conclusions

The constitutional model of administrative discretion in Ukraine is characterized by inefficiency. Such administrative discretion does not allow the bureaucracy to be flexible and effective. The reasons are in the limited constitutional model of administrative discretion. According to the Ukrainian constitution, a public authority is restricted by law. Limiting the law means that there is a planning element in this model. Parliament, which creates laws, should provide all possible situations of public administration and create rules that will fully regulate the activities of a governmental body or official. However, this task is theoretically unrealistic. Parliament cannot create perfect laws for government since it is impossible to predict all situations that may arise in public administration. In fact, such a model does not fully take into account the spontaneous order. Expanding of administrative discretion will help to resolve this problem. In this situation, public officials will be able to be more flexible and better respond to public administration issues. Besides, it is important to ensure the control over public officials in order to eliminate abuse of power.

In order to satisfy all these requirements, a creation of a new constitutional model of administrative discretion is needed. Such a model has to limit administrative discretion through legal principles, but not through the laws. Legal principles as restriction are more in line with the spontaneous order and should improve the activity of public officials. Administrative courts are an important element in such a model because they will provide judicial review of discretionary administrative acts. 


\section{Bibliography}

1. Calabresi S.G. Friedrich A. Hayek, the U.S. constitution, and institutional design. Arizona State Law Journal. 2016. April 5. P. 232-240.

2. Clayton S.A. Judicial Review of Administrative Discretion: How Justice Scalia and Breyer Regulate Regulators. El Paso : LFB Scholarly Publishing LLC, 2015. 190 p. URL: http://ebookcentral.proquest.com/lib/luc/detail.action?docID $=4395954$.

3. Constitution of Ukraine : Adopted at the Fifth Session of the Verkhovna Rada of Ukraine on 28 June 1996. Official Translation. Kyiv : Ukrainian Legal Foundation, 1998. 48 p. URL: http://extwprlegs1.fao.org/docs/pdf/ukr127467E.pdf.

4. Devins C., Koppl R., Kauffman S. et al. Against Design. Arizona State Law Journal. 2015. February 25. P. 609-681.

5. Dicey A.V. Introduction to the Study of the Law of the Constitution. Six ed. New York : Macmillan \& Co., 1902. 230 p.

6. Hayek F.A. von. Law, Legislation and Liberty: A New Statement of the Liberal Principles of Justice and Political Economy. London : Routledge \& Kegan Paul, 1982. 645 p.

7. Keeler R.L. Managing Outsourced Administrative Discretion. State and Local Government Review. 2013. № 45(3). P. 183-188.

8. Code of Administrative Legal Process of Ukraine of July 6, 2005 № 2747-IV (the last edition from October 2, 2018). URL: http://cis-legislation.com/document.fwx?rgn=10720.

\section{References:}

1. Calabresi, S.G. (2016). Friedrich A. Hayek, the U.S. constitution, and institutional design. Arizona State Law Journal, April 5, pp. 232-240 [in English].

2. Clayton, S.A. (2015). Judicial Review of Administrative Discretion: How Justice Scalia and Breyer Regulate Regulators. El Paso: LFB Scholarly Publishing LLC. Retrieved from: http:// ebookcentral.proquest.com/lib/luc/detail.action?docID=4395954 [in English].

3. Verkhovna Rada of Ukraine (1998). Constitution of Ukraine: Adopted at the Fifth Session of the Verkhovna Rada of Ukraine on 28 June 1996. Official Translation. Kyiv: Ukrainian Legal Foundation. Retrieved from: http://extwprlegs1.fao.org/docs/pdf/ukr127467E.pdf [in English].

4. Devins, C., Koppl, R., Kauffman, S. et al. (2015). Against Design. Arizona State Law Journal, February 25, pp. 609-681 [in English].

5. Dicey, A.V. (1902). Introduction to the Study of the Law of the Constitution. Six ed. New York: Macmillan \& Co. [in English].

6. Hayek, F.A. von. (1982). Law, Legislation and Liberty: A New Statement of the Liberal Principles of Justice and Political Economy. London: Routledge \& Kegan Paul [in English].

7. Keeler, R.L. (2013). Managing Outsourced Administrative Discretion. State and Local Government Review, no. 45(3), pp. 183-188 [in English].

8. Verkhovna Rada of Ukraine (2005). Code of Administrative Legal Process of Ukraine of July 6, 2005 № 2747-IV. Retrieved from: http://cis-legislation.com/document.fwx?rgn=10720 [in English]. 


\title{
КОНСТИТУЦІЙНА МОДЕЛЬ АДМІНІСТРАТИВНОГО РОЗСУДУ В УКРАЇНІ: ДИЗАЙН ЧИ СПОНТАННИЙ ПОРЯДОК
}

\author{
Олександр Сидєльніков, \\ здобувач ступеня магістра права (LL.M.) в Інституті верховенства права для розвитку, \\ Школа права Університету Лойоли Чикаго - Римський центр Джона Феліче, \\ кандидат юридичних наук \\ o.sydielnikov@gmail.com
}

Мета дослідження - проаналізувати конституційну модель адміністративного розсуду в Україні крізь призму теорії Ф.А. Хаєка про дизайн і спонтанний порядок. Також доиільно запропонувати зміни щзодо вдосконалення моделі адміністративного розсуду в Україні.

Методи. Якісний метод дослідження був основним у статті. Традиційний (або неемпіричний) юридичний дослідницький підхід також використовувався автором під час дослідження моделі адміністративного розсуду в Украӥні.

Результати. У статті автор розглядає проблему неефективності моделі адміністративного розсуду в Україні. Розпочинається аналіз проблематики 3 критики положень частини 2 статті 19 Конституиії України. Обмеження законом адміністративного розсуду суб'єктів публічного адміністрування визнається неефективним. Причинами неефективності моделі адміністративного розсуду, на думку автора, є ігнорування елементу спонтанності в процесі розроблення законодавства. Таким чином, автор використовує концепцію спонтанного порядку, яка належить австрійському економісту Ф.А. Хайєку. Згідно із цією концепцією недоліком системи планування є неможливість передбачити всі ситуачії, які можуть виникнути в реальному житті. Цей висновок можна застосувати також до процесу створення законодавства. Відповідно, автор робить висновок про те, що закони не можуть запропонувати ідеальні правила поведінки для державних службовиів.

Висновки. Таким чином, обмеження адміністративного розсуду положеннями закону не є ефективним. У статті пропонується обмежити адміністративний розсуд не законом, а правовими принципами. На думку автора, такий підхід дасть змогу врахувати елемент спонтанності в публічному адмініструванні. Водночас автор підкреслює, щу роль судового перегляду адміністративних актів за такої моделі суттєво зростає.

Ключові слова: адміністративний розсуд, спонтанний порядок, конституційний дизайн, публічне адміністрування. 